\title{
The Arctic Skua Stercorarius parasiticus L. in northwest Hornsund, Spitsbergen, summer of 1980
}

\author{
IZABELLA DUNIN-KWINTA AND OLGIERD ROZYCKI
}

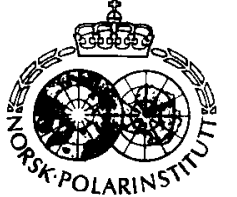

Dunin-Kwinta. I. \& Rozycki, O. 1984: The Arctic Skua Stercorarius parasiticus L. in northwest Hornsund. Spitsbergen, summer of 1980. Polar Research 3 n.s., 127-128.

Izabella Dunin-Kwinta and Olgierd Rozycki, Maritime Academy, Waly Chrobrego 1, 70-500 Szczecin. Poland.
The Arctic Skua stercorarius parasiticus was observed on the northwestern coast of Hornsund from 8 July to 2 September 1980 , on the coastal tundra from Worcesterpynten to the mouth of the Bratteg river, and on the south bank of the river to its outflow from the Myrktjønna lake. A coastal belt with about $15.1 \mathrm{~km}$ of shoreline and about $5.74 \mathrm{~km}^{2}$ of tundra was covered. The density of breeding pairs, clutch and egg size, hatching success, distribution, and seasonal variability of abundance of birds were noted.

In the study area, 11 nests of Arctic Skua were found; their locations are presented in Fig. 1. Ten nests were found very close to the water line, about $100-200 \mathrm{~m}$ from the shore and

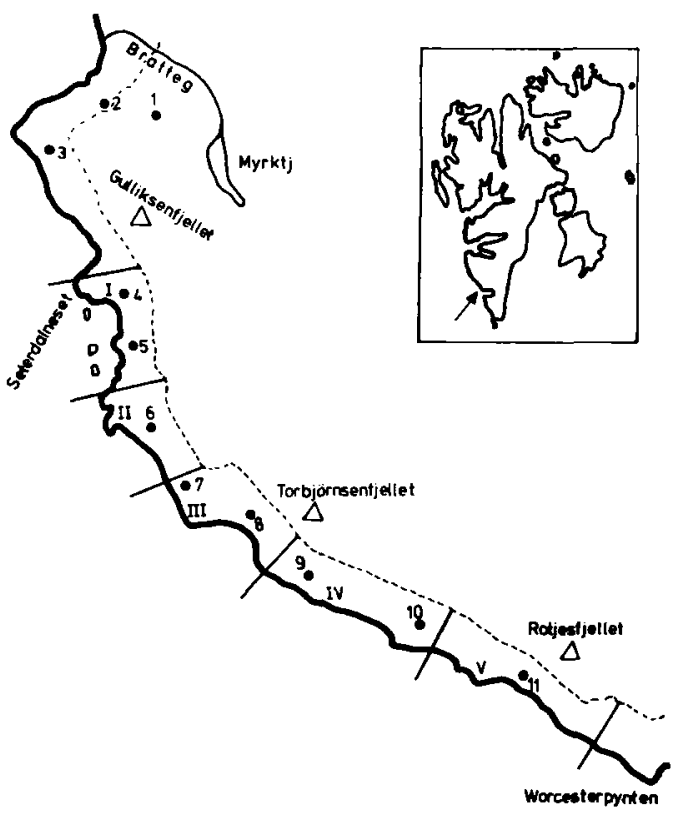

Fig. 1. Location and distribution of Arctic Skua Stercorarius

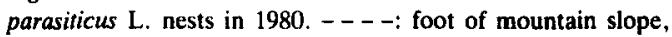
I-V: sector borders, 1-11: Arctic Skua nests and Nos.
Table 1. Egg sizes of Arctic Skua in various nests in Hornsund in 1980 .

\begin{tabular}{|c|c|c|}
\hline Nest No. & $\begin{array}{l}\text { Egg } \\
\text { length - width } \\
(\mathrm{mm})\end{array}$ & $\begin{array}{l}\text { Mean size }(\mathrm{mm}) \text { of egg } \\
\text { in nest } \\
\text { length - width }\end{array}$ \\
\hline 1 & $\begin{array}{l}63.1-42.2 \\
66.2-42.0\end{array}$ & $64.6-42.1$ \\
\hline 2 & $\begin{array}{l}62.0-41.3 \\
62.2-42.1\end{array}$ & $62.1-41.7$ \\
\hline 3 & $\begin{array}{l}63.1-41.0 \\
63.0-41.3\end{array}$ & $63.0-41.1$ \\
\hline 4 & $\begin{array}{l}62.2-43.1 \\
65.0-43.1\end{array}$ & $63.6-43.1$ \\
\hline 5 & $\begin{array}{l}63.1-42.2 \\
65.1-42.1\end{array}$ & $64.1-42.1$ \\
\hline 6 & $\begin{array}{l}64.1-41.5 \\
64.3-41.6\end{array}$ & $64.2-41.5$ \\
\hline 7 & $\begin{array}{l}66.3-42.6 \\
63.1-41.7\end{array}$ & $64.7-42.1$ \\
\hline 8 & $\begin{array}{l}67.0-43.1 \\
64.5-42.7\end{array}$ & $65.7-42.9$ \\
\hline 9 & $\begin{array}{l}67.3-42.5 \\
65.3-43.2\end{array}$ & $66.3-42.8$ \\
\hline 10 & $\begin{array}{l}62.6-41.4 \\
66.1-43.2\end{array}$ & $64.3-42.3$ \\
\hline 11 & $\begin{array}{l}67.1-43.1 \\
65.3-42.3\end{array}$ & $66.2-42.7$ \\
\hline $\begin{array}{l}\text { Mean } \\
\text { Standard deviation } \\
\text { Standard error } \\
\text { of the mean } \\
\text { Coefficient } \\
\text { of variation }(\%)\end{array}$ & $\begin{array}{c}64.4-42.2 \\
7.52-1.98 \\
1.60-0.42 \\
11.68-4.72\end{array}$ & \\
\hline
\end{tabular}

about $700-1850 \mathrm{~m}$ apart. Only one nest was placed more inland, close to the Bratteg river and about $900 \mathrm{~m}$ from the shore. Most nests were placed about $200-400 \mathrm{~m}$ from the mountain slopes inhabited by Little Auks Alle alle. Mean densities of nesting 
pairs were 0.7 per $\mathrm{km}$ of coastline and 1.9 per $\mathrm{km}^{2}$ of tundra, the densities being higher than those recorded by Jakubiec (1982) in Hornsund in 1973 on analogous terraces (0.8-1.7 pairs per $\mathrm{km}^{2}$ ) and similar to those reported for 1964 by Gullestad (1977) in terms of all pairs encountered (including those for which no nest could be found).

Two-egg clutches were observed in all nests. In 1980 the average clutch-size was larger than before. As recorded by Ferens (1962), there was usually only one egg per nest in Hornsund in 1957. As recorded by Gullestad (1977), 18\% of the nests had one egg in 1964.

The hatching success was checked on 24 July. Out of eleven nests, eight (Nos. 4-11) were scattered from Worcesterpynten to Seterdalneset and contained empty shells, while intact eggs were found in the remaining nests (Nos. 1-3). Based on the shells found, seven out of eight nests left by chicks showed the hatching success to equal the number of eggs laid; in one nest one egg failed to hatch (checked on several occasions later). Some eggs presumably hatched before and others after $20 \mathrm{July}$. This assumption is based on observations by Gullestad (1977), who found that Arctic Skua chicks were able to hide so well only a few days after birth that it was impossible to find them. On 24 July 1980, only some chicks were seen and the rest could not be found. Considering the fact that three nests still contained intact eggs on 24 July, hatching lasts for at least five days in the area.

Distribution and seasonal variability of abundance of skuas were recorded in the area between Seterdalneset and Worcesterpynten, where eight nests (Nos. 4-11) were found. This is a coastal belt, about $8.5 \mathrm{~km}$ long, covering $4.0 \mathrm{~km}^{2}$ of tundra restricted by an about $11.4 \mathrm{~km}$ long shoreline. The area was divided into five sectors (I-V). Each sector contained one or two nests of Arctic Skua, as illustrated in Fig. 1. All the skuas spotted through $11 \times 40$ binoculars on the tundra and above the water were recorded at five-day intervals from 8 July to 23 August. The birds were always counted from the same spot and at the same time of the day. Based on a total of 45 observations the following may be said:

- Busy with incubation and brood protection, the Arctic Skua moves over a limited area. Both parents are very active in protecting the eggs and nestlings and remain close to the nest for fear of danger; they can, however. operate more than $250 \mathrm{~m}$ away from the nest.

- The death of one parent bird was recorded among the eight nesting pairs, but a single lone bird managed to raise two chicks.

- At the beginning of the summer of 1980,16 individuals of Arctic Skua started to breed in the area. Two months later, as a result of breeding and mortality, probably 29 skuas were present.

\section{References}

Ferens, B. 1962: Notes on the behaviour and activity of birds during the polar day in the Arctic. Zesz. Nauk. Uniw. Jagiell 50, Zool. 6. Kraków.

Gullestad, N. 1977: Observasjoner av tyvjo (Stercorarius parasiticus) i Hornsund, Spitsbergen, 1963 og 1964. Nor. Polarinst. Arbok 1976, 371-373.

Jakubiec, Z. 1982: A quantitative investigation on birds of the Hornsund Region, SW Spitsbergen. Acta Univ. Wratisl. 525(4), 77-91. Wroclaw. 